\title{
A highly divergent mitochondrial DNA lineage of Microtus agrestis in southern Europe
}

\author{
M Jaarola ${ }^{1}$ and JB Searle ${ }^{2}$ \\ ${ }^{1}$ Department of Cell and Organism Biology, Genetics, Lund University, Sölvegatan 29, SE-223 62 Lund, Sweden; ${ }^{2}$ Department of \\ Biology, University of York, PO Box 373, York YO10 5YW, UK
}

\begin{abstract}
The Mediterranean peninsulas constitute important areas for endemism and intraspecific variation, and are likely places for cryptic biodiversity. We assessed the phylogeographic pattern of field voles (Microtus agrestis) in southern and central Europe by sequence analysis of a 385-bp fragment of the mitochondrial cytochrome $b$ gene in 74 specimens from 44 localities. The majority of samples consisted of skulls collected from owl pellets. The data revealed a highly distinct cytochrome $b$ lineage in an area ranging from Portugal to Hungary. This southern field vole phylogroup differed by a
\end{abstract}

Keywords: phylogeography; mtDNA; cryptic taxa; Microtus agrestis; cytochrome b; biodiversity

sequence divergence of 5.6-7.1\% from the remaining haplotypes, a level of divergence comparable to that found between known Microtus sibling species. However, this ancient phylogeographic break that dates back many glacial cycles has not been recognised previously by either morphology or karyotype. The southern cytochrome $b$ lineage was further divided into two well-defined sublineages that appear to have derived from different glacial refugia in the Iberian Peninsula. Heredity (2004) 92, 228-234, advance online publication, 3 December 2003; doi:10.1038/sj.hdy.6800400

\section{Introduction}

In a variety of types of organism, molecular genetic studies have revealed 'cryptic' taxa that exhibit considerable genetic divergence from their closest relative despite little or no morphological differentiation. This decoupling of molecular and morphological evolution has been observed both within and between species (eg Sullivan et al, 1997; Riddle et al, 2000). The existence of cryptic biological diversity has wide-ranging implications for both ecological and evolutionary studies as well as for the preservation of biodiversity.

In Europe, the southern, Mediterranean area has the greatest diversity of recognised species among plants, insects, small mammals and other groups (Blondel and Aronson, 1999; Mitchell-Jones et al, 1999). This diversity includes many endemic species (Bilton et al, 1998; Myers et al, 2000) and there is also substantial intraspecific genetic variation in many species (Taberlet et al, 1998; Hewitt, 1999, 2000). In these southern areas, species have been able to survive glaciations and diversify genetically through geographic isolation in different Mediterranean peninsulas and in different parts of those peninsulas. These are just the circumstances where cryptic biological diversity may be expected. In this paper, we describe a cryptic south European small mammal, discovered during our studies directed at the field vole (Microtus agrestis).

The field vole is a widespread and common species in Eurasia. Previous restriction enzyme analyses demon-

Correspondence: $M$ Jaarola, Department of Cell and Organism Biology, Genetics, Lund University, Sölvegatan 29, SE-223 62 Lund, Sweden.

E-mail: Maarit.Jaarola@cob.lu.se

Received 28 November 2002; revised 3 June 2003; accepted 10 August 2003 strated a western and eastern mitochondrial (mt) DNA lineage in Fennoscandia (Jaarola and Tegelström, 1995, 1996; Jaarola et al, 1999). Subsequent phylogeographic studies using mtDNA sequences have extended these studies elsewhere in the species' range (Jaarola and Searle, 2002). The data show that the western mtDNA lineage also occurs in central parts of west Europe, and that an additional mtDNA lineage can be found in southern Europe. This paper describes the highly divergent southern mtDNA lineage and its unusual geographic distribution in detail. The southern field vole lineage presents a particularly striking example of a cryptic taxon.

\section{Materials and methods}

\section{Samples}

Field vole samples from 44 localities covering the species' range in southern and central Europe were surveyed (Figure 1). Much of the material consisted of skulls collected from owl pellets. Other samples consisted of feet, tail tips, ears or liver preserved dried, frozen or in absolute ethanol. Of the 74 individuals considered here, 25 were reported in a previous study by Jaarola and Searle (2002).

DNA extraction, PCR amplification and DNA sequencing Initially, a standard phenol-chloroform protocol was used to extract total genomic DNA from tissue samples and a silica-based method for the skulls (Taberlet and Fumagalli, 1996). Later the Qiagen Dneasy ${ }^{\mathrm{TM}}$ Tissue kit was used for all types of samples. For the skulls, DNA was extracted from the mandibles or cranial fragments. Owing to the extensive degradation of DNA in the skull samples, only a 385-bp fragment in the central part of the 


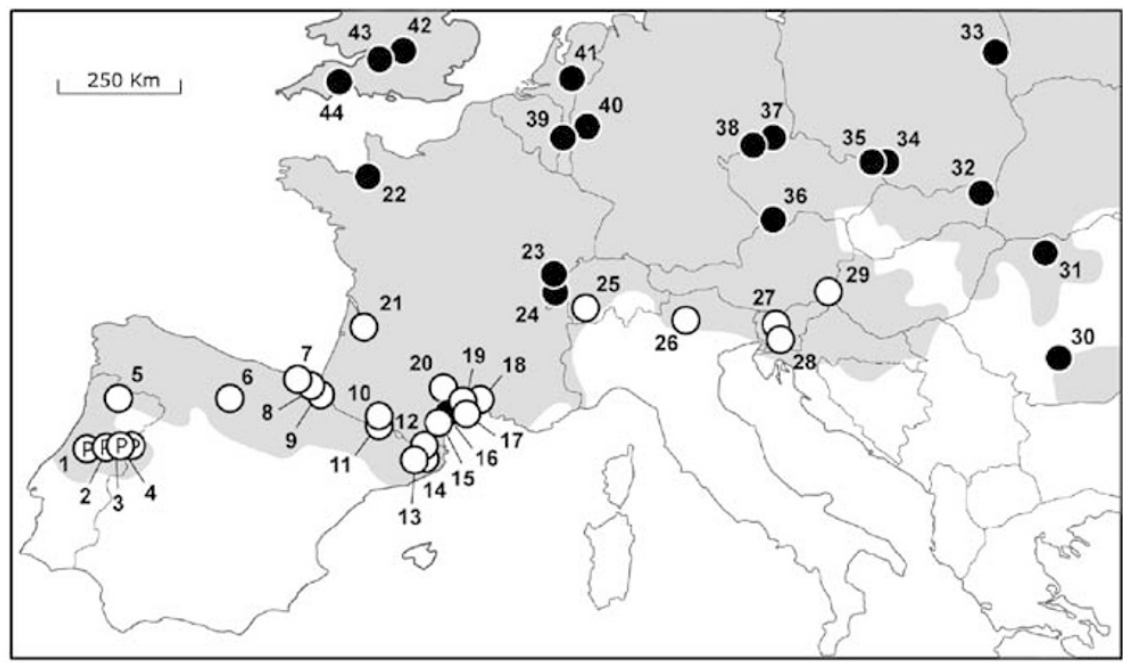

Figure 1 Map showing the sampling localities and the field vole (Microtus agrestis) range (shaded) in southern and central Europe, and the geographic distribution of the southern (open circles) and western (filled circles) cytochrome $b$ lineages. The range of the Portuguese sublineage $(\mathrm{P})$ is also depicted. The distribution range is redrawn after Mitchell-Jones et al (1999). Numbers represent the following localities: Portugal: 1 - Miranda do Corvo, 2 - Serra da Estrela, 3 - Belmonte, 4 - Sabugal, 5 - Cabeceiras de Basto; Spain: 6 - Melgae de Fernamental, 7 Azpeitia, 8 - Oronoz, 9 - Eugui, 10 - Sant Juan de Toran, 11 - Vall d'Aran, 12 - Roda de Ter, 13 - Cantonigros, 14 - Sant Pere Despuig; France: 15 - Narbonne, 16 - Portiragnes, 17 - Vic-La-Gardiole, 18 - Lansargues, 19 - Mireval, 20 - St Rome de Berlieres, 21 - La Force, 22 - Mont SaintMichel, 23 - Combe d'Oregeval; Switzerland: 24 - Vallée de Joux, 25 - Sion; Italy: 26 - Cavalese; Slovenia: 27 - Ljubljana, 28 - Ribnica; Hungary: 29 - Örseg; Romania: 30 - Valea Brazilor, 31 - Sǎpânta; Poland: 32 - Cisna, 33 - Bialowiez̀a, 34 - Pilchowice, 35 - Kuznia Raciborska; Czech Republic: 36 - Kladenské Rovne, 37 - Filipov, 38 - Fláje; Belgium: 39 - Bihain; Germany: 40 - Bonn; Netherlands: 41 - Heteren; England: 42 Shotover, 43 - Grittenham, 44 - Rewe.

cytochrome $b$ gene could be amplified consistently. For this purpose, we used four field-vole-specific primers: L15162M (5'-GCAAGGTACTTCCATGAGGA CAAATATC-3') (modified from Irwin et al, 1991) and L15162M2, and H15549M and H15576M (Jaarola and Searle, 2002). Some tissue samples were used to amplify the complete cytochrome $b$ gene with the Microtusprimers L14727-SP and H-ISO-SP (Jaarola and Searle, 2002).

To avoid confusion of true mitochondrial sequences with mitochondrial pseudogenes in the nucleus (Mirol et al, 2000; Bensasson et al, 2001), we made three test studies. First, we compared sequences obtained from PCR products amplified both from pure mtDNA (Jaarola and Tegelström, 1995) and total DNA in three individuals. Second, we compared five 385-bp sequences to those obtained from amplification of the whole cytochrome $b$ gene. Third, we cloned two PCR products and sequenced up to five clones using the pGEM-T Easy system (Promega) combined with the Bluescript II Exo/ Mung DNA sequencing system (Stratagene).

Frozen and ethanol-preserved tissue samples were amplified using standard protocols. Skull DNAs were initially amplified using the standard protocol followed by a re-PCR with the same set of primers. Most skull samples, however, as well as the dried tissue samples, were amplified using a 'Time Release PCR' approach involving 10 extra amplification cycles and stepwise activation of AmpliTaq Gold polymerase (Applied Biosystem). This approach is useful in very-low template copy number applications, such as the skull DNA samples.

PCRs were performed using $1.8 \mathrm{U}$ of AmpliTaq Gold DNA polymerase and $5 \mu \mathrm{l}$ of Gold Buffer (Applied Biosystems) in $50 \mu \mathrm{l}$ final volumes. Amplification was carried out for 46 cycles $\left(1 \mathrm{~min}\right.$ at $95^{\circ} \mathrm{C}, 1 \mathrm{~min}$ at $49^{\circ} \mathrm{C}$ and $1 \mathrm{~min}$ at $72^{\circ} \mathrm{C}$ ) followed by an 8 -min additional step at $72^{\circ} \mathrm{C}$. Each DNA fragment was sequenced in both directions with the PCR primers, and run on ABI 377, 310 or 3100 (Applied Biosystems) automated DNA sequencers.

\section{Data analysis}

We aligned sequences and resolved ambiguous bases using the Sequencher v. 3.1.1 software (Gene Codes Corp.). Nucleotide and amino-acid composition was analysed using MacClade v. 4.03 (Maddison and Maddison, 2000). Phylogenetic analyses based on maximum parsimony (MP), maximum likelihood (ML) and neighbour-joining (NJ) algorithms were conducted in PAUP v. 4.0b10 (Swofford, 1998). Parsimony analyses of the whole data set were carried out 20 times with the heuristic search approach using the TBR swapping algorithm, steepest descent option and simple or closest addition replicates. Subsets of the data were analysed using the branch-and-bound option. The ML tree search was conducted as described for MP but with the 'as is' addition replicate. Following our findings with Modeltest v. 3.06 (Posada and Crandall, 1998), ML and NJ analyses were performed using the Kimura 3-parameter (K81) substitution model (Kimura, 1981) with and without a gamma distribution shape parameter of $\alpha=0.08$. We also tested simpler substitution models. The relative stability of the MP and NJ trees was assessed by bootstrapping with 5000 and 10000 replicates, respectively. In addition, we used MacClade to analyse the MP trees and to manually construct an MP network. A statistical parsimony network was constructed by using the TCS program v. 1.13 (Clement et al, 2000). 
Representative haplotypes of the western and eastern cytochrome $b$ lineage as well as a $M$. kirgisorum and a M. juldaschi cytochrome $b$ sequence were tested as outgroups.

Pairwise distances between haplotypes and nucleotide diversity $(\pi)$ and raw and net divergence (Dxy and Da; Nei, 1987) between phylogroups were estimated in $M E G A$ v. 2.1 (Kumar et al, 2001) using Kimura 2parameter distances (Kimura, 1980). Standard errors (SE) were estimated by the bootstrap method using 10000 replicates. Divergence time $(T)$ between phylogroups was estimated as $T=\mathrm{Da} / 2 \mu$ where $2 \mu$ is the divergence rate, while $95 \%$ confidence intervals for the divergence times were calculated as $\pm 1.96 \mathrm{SE}$ of the net distances.

\section{Results}

\section{Skull analyses}

We obtained the expected 385-bp PCR product from skulls up to at least 32 years old. Altogether 48 out of the 71 skulls analysed generated PCR products, and 37 of these fragments generated unambiguous mtDNA sequences. The ultimate success rate of the skull DNA analyses was thus 52\%. The method involving the Qiagen Dneasy ${ }^{\mathrm{TM}}$ Tissue kit and the AmpliTaq Gold DNA polymerase clearly performed better than the alternative method.

Where ambiguous sequences were generated, our cloning studies revealed that this frequently might have been the result of a damaged DNA template (see Wayne et al, 1999). However, several of the ambiguous sequences also represented a nuclear pseudogene or a mixture of a pseudogene and the mitochondrial cytochrome $b$ gene. While mtDNA sequences would normally be in considerable excess relative to nuclear pseudogenes, perhaps the poor preservation of the skulls from owl pellets increased the likelihood that nuclear pseudogenes were amplified. The pseudogenes will be described in more detail elsewhere (Jaarola et al, unpublished). Here, we only describe those sequences from skulls that were unambiguously mitochondrial, based on comparison with sequences from pure mtDNA preparations (see Materials and methods) and with numerous whole and partial cytochrome $b$ sequences from tissue samples (this study and Jaarola and Searle, 2002).

\section{Phylogeographic analyses}

Skull and tissue samples from a total of 74 individuals, representing 33 haplotypes, yielded 385-bp cytochrome $b$ sequences without ambiguities (Table 1). Altogether 18 of these haplotypes were represented in the 25 individuals reported previously (Jaarola and Searle, 2002) and have GenBank Accession Numbers AY167151-167212 in Table 1 . The 15 new haplotypes observed have also been deposited in GenBank (Accession Numbers AY303151AY303165; Table 1). Sequence composition and nucleotide substitution patterns were similar to that reported for the whole cytochrome $b$ gene in the field vole (Jaarola and Searle, 2002). Altogether five amino-acid replacements were observed, all of which occurred within the variable matrix and transmembrane region (cf Irwin et al, 1991).
Of the 53 segregating sites observed (Table 1), 38 were informative for the parsimony analyses. Outgroup rooting with $M$. kirgisorum generated the highest bootstrap support and the shortest MP trees. The $21 \mathrm{MP}$ trees (115 steps, $\mathrm{CI}=0.73$ ) as well as the ML and the NJ tree (Figure 2) discriminated two strongly supported major cytochrome $b$ assemblages. One of these two lineages (27 specimens, 17 haplotypes) corresponds to the western lineage first described in Fennoscandia (Jaarola and Tegelström, 1995, 1996). This lineage is considered elsewhere in analyses involving the whole cytochrome $b$ gene (Jaarola and Searle, 2002). The second lineage (47 specimens, 16 haplotypes) represents the southern mtDNA lineage. The geographic distribution of the southern lineage comprised Portugal, northern Spain, southern France, Switzerland, Slovenia and westernmost Hungary (Figure 1). The nucleotide diversity within the southern and western phylogroup was $1.8 \pm 0.3 \%(\pi \pm \mathrm{SE})$ and $1.4 \pm 0.3 \%$, respectively. The raw divergence between the two phylogroups was estimated at $7.1 \pm 1.2 \%$ and the net divergence was $5.6 \pm 1.1 \%$.

We observed 28 variable nucleotide positions among the 16 southern lineage haplotypes (Table 1). The MP analyses of the 17 informative sites generated two to four minimum trees. The trees only differed in the position of haplotype S3-S5. The unrooted parsimony network presented in Figure 2 is obtained when designating haplotype S1 as the basal haplotype for haplotypes S3-S5 according to the coalescent approach of Crandall and Templeton (1993). The TCS analyses generated the same network.

High bootstrap values supported the existence of two well-defined southern sublineages (Figure 2) differing by a raw and net divergence of $4.3 \pm 0.9$ and $3.8 \pm 0.9 \%$, respectively, and including one amino-acid difference. The range of one of these sublineages appears to be restricted to Portugal; the other sublineage is distributed from Portugal to Hungary (Table 1, Figures 1 and 2). The nucleotide diversity within the two subphylogroups was estimated at $0.2 \pm 0.2$ and $0.8 \pm 0.2 \%$, respectively.

\section{Discussion}

\section{A cryptic and ancient evolutionary unit}

Our analyses show that field voles from southern Europe belong to a highly divergent cytochrome $b$ lineage. Although it has been demonstrated that large-scale phylogeographic patterns often reflect long-term population histories (Barton and Wilson, 1995; Avise, 2000), the randomness of the coalescent process makes inferences about evolutionary histories from genealogies difficult (Nordborg, 2001). Consequently, as we have only used one genetic marker, it could be argued that the southern phylogroup may not correspond to a population with a specific evolutionary history, but merely mirror the mtDNA genealogy. Moreover, the southern mtDNA phylogroup in the field vole does not correspond to a recognised subspecies defined by morphology, nor a karyotypic race (cf. Almaça, 1993; Mathias et al, submitted). It is of course possible that diagnostic morphological characters exist, but if so, they have not been described to date to our knowledge. The existence of a highly divergent, cryptic Microtus population in southern Europe is, however, strongly supported by both $\mathrm{X}$ and $\mathrm{Y}$ 
Table 1 Polymorphic positions of the 33 cytochrome $b$ haplotypes of the field vole, their distribution across the sample localities and their GenBank accession numbers

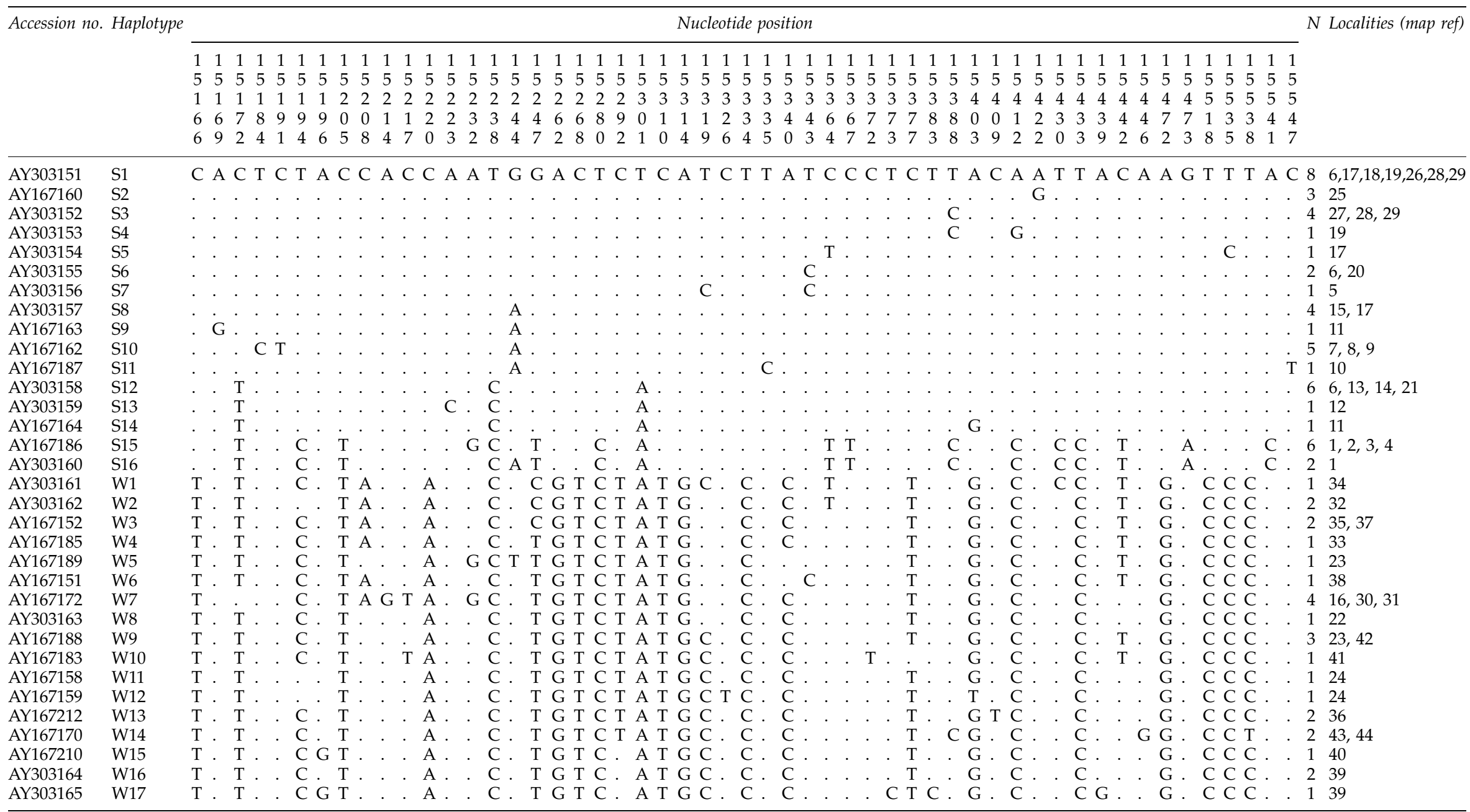

Nucleotide positions are numbered according to the human sequence (Anderson et al, 1981). 

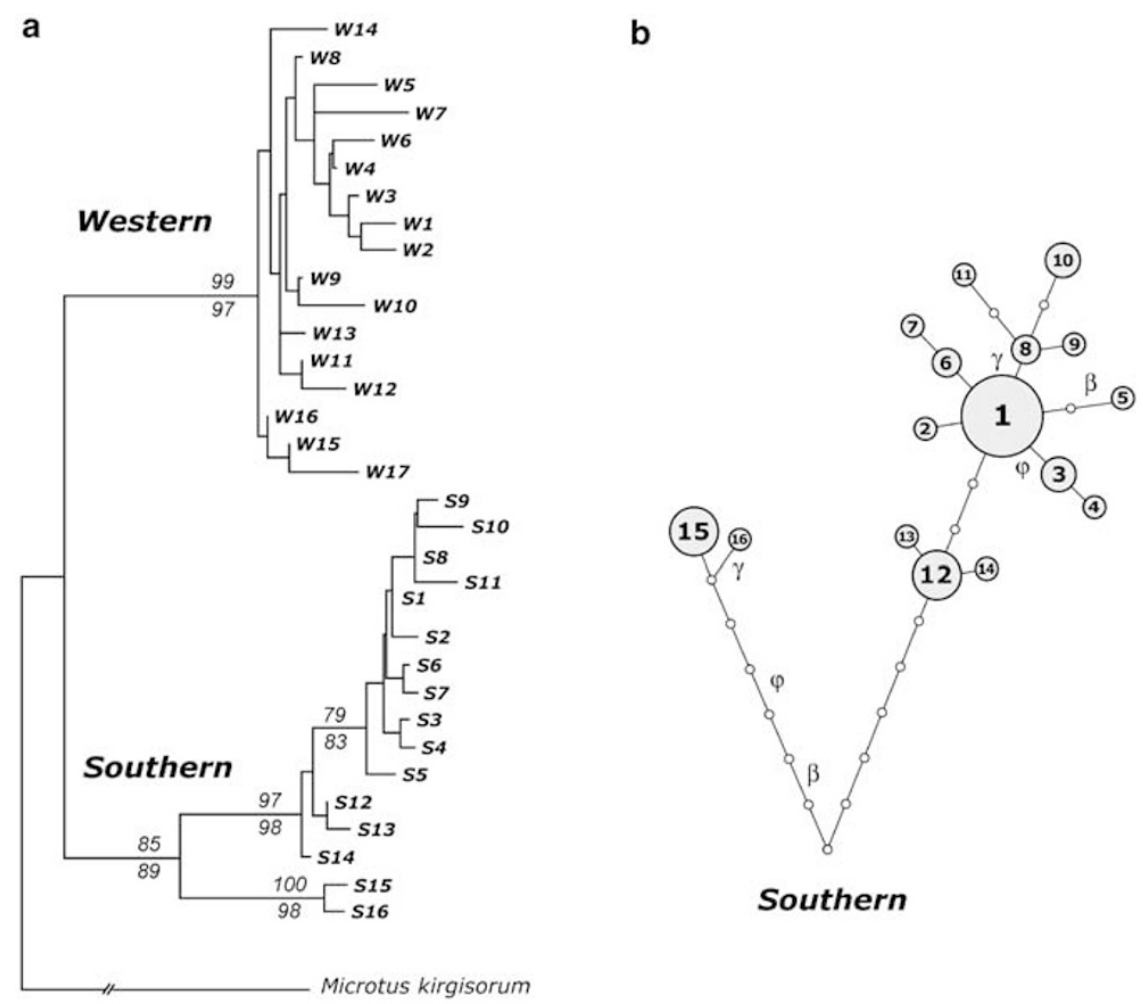

Southern

$5 \%$

Figure 2 (a) NJ tree constructed from Kimura 3-parameter distances between the 33 field vole 385-bp cytochrome $b$ haplotypes. Values above and below branches indicate percentage bootstrap support ( $>70 \%$ ) for the NJ and MP trees, respectively. (b) An unrooted MP network of the 16 cytochrome $b$ haplotypes observed in the southern field vole lineage. Small, white circles represent hypothetical haplotypes not found in the sample. Circle size is proportional to the number of localities $(n=1-7)$. The network, which is 32 steps long $(\mathrm{CI}=0.91)$, contains three homoplasies (position $15244=\gamma, 15364=\beta, 15388=\varphi$ ) and one position (15412) with two mutations (see Table 1 ).

chromosome sequence genealogies displaying reciprocal monophyly. Furthermore, the geographical distributions of the major phylogenetic lineages are congruent among the three genetic markers available (Hellborg, Gündüz and Jaarola, manuscript). These data clearly demonstrate that the southern mtDNA phylogroup represents an independent evolutionary trajectory.

The divergence of $5.6-7.1 \%$ between the southern and western cytochrome $b$ phylogroups in the field vole is very large. A similar estimate of divergence $(4.8-6.0 \%)$ is obtained between different sets of southern and western lineage animals using the entire 1140-bp cytochrome $b$ gene (Jaarola and Searle, 2002), so the estimate is not biased due to the short sequence analysed in this study. In fact, the divergence within the field vole is comparable to divergence levels observed between Microtus sibling species (Conroy and Cook, 2000b). For example, the cytochrome $b$ divergence between the common vole ( $M$. arvalis) and the sibling vole (M. rossiaemeridionalis) is $7.0 \%$ (Haynes et al, 2003). However, high levels of intraspecific cytochrome $b$ variation are found in several Microtus species (eg Conroy and Cook, 2000a), and intra- and interspecific distances therefore overlap (Jaarola et al, submitted).

Available data suggest that the divergence rate of the cytochrome $b$ gene in Microtus is high, and probably similar to the rates suggested for other rodents (Conroy and Cook, 2000b). Application of a rodent 6-10\% divergence rate per million years (Myr) would suggest that the southern field vole lineage is $0.6-1.2 \mathrm{Myr}$ old (95\% CI $=0.3-1.6 \mathrm{Myr})$. Thus, irrespective of applying a fast, rodent-specific molecular clock or a slower, 'traditional' clock, it is clear that the southern mtDNA phylogroup has an ancient evolutionary history that traces back many glacial cycles.

\section{A new mammal species?}

Our results demonstrate a morphologically cryptic but ancient and genetically highly divergent evolutionary unit in southern Europe, and it would be tempting to suggest that this population represents a new species. It is well known for cryptic/sibling species to be described initially by molecular, karyotypic, ecological or behavioural characters and for minor morphological features to be detected later. For example, the European shrews Sorex araneus and $S$. coronatus were first distinguished by karyotype and later by mandibular morphology (Hausser and Jammot, 1974). Similarly, the European bats Pipistrellus pipistrellus and P. pygmaeus were identified by echolocation call, ecology and molecular differences (Barratt et al, 1997). Minor differences in skull measurements were found subsequently (Barlow et al, 1997).

If the southern phylogroup constitutes a new species, this would be noteworthy in the context of European mammalogy. Although the taxonomy of European Microtus has changed greatly in the last 20 years, all of the 15 species currently described (Mitchell-Jones et al, 
1999) are mentioned in Corbet (1978) as species or subspecies. However, more data are needed before the recognition of the southern phylogroup as a separate species. For example, the extent of reproductive isolation in areas of contact between the southern and western lineage should be investigated. Southern or central France and western Switzerland constitute probable contact areas (Figure 1). In addition, captive breeding studies would be worthwhile.

The distributions of the western and southern phylogroups in the field vole do not fit the patterns normally associated with postglacial expansion of lineages within species in Europe (cf Taberlet et al, 1998; Hewitt, 1999, 2000). In fact, the unusual geographic distribution of the southern mtDNA phylogroup in the field vole may be indicative of it representing a separate species adapted to Mediterranean environments including upland areas (Figure 1). The occurrence of the southern phylogroup in Iberia suggests that it survived there during the last glaciation, and that the western phylogroup probably occupied a glacial refugium in the Carpathians (Jaarola and Searle, 2002). If these two phylogroups belong to the same species, and successfully colonized northwards at the end of the last glaciation, they would be expected to have a relatively westerly and easterly distribution, respectively. However, instead, the two phylogroups have relatively southerly and northerly distributions (Figure 1). This pattern would be expected if the western phylogroup spread first through central Europe, with subsequent displacement from southern areas by a separate species - the southern phylogroup - better adapted to Mediterranean conditions. The distributions of other sibling species of small mammal, the shrews S. araneus/coronatus and the water voles Arvicola terrestris/ sapidus (Mitchell-Jones et al, 1999), appear to have originated in similar ways, with $S$. coronatus and A. sapidus representing species deriving from Iberian glacial refugia, displacing $S$. araneus and $A$. terrestris, respectively, from parts of their widespread central European ranges (Searle, 1984). It is noteworthy that field voles in the most easterly localities of the southern lineage (25-29; Switzerland, Italy, Slovenia and Hungary) either carry a haplotype also found in Spain and France (S1) or haplotypes that differ from this by only one nucleotide (S2, S3; Table 1). Thus, the nucleotide diversity, $\pi$, is only $0.2 \%$ in the eastern area from Switzerland to Hungary (localities 25-29) whereas those from the west, in Spain and France (localities 6-15, 1721 ), exhibit a value of $0.9 \%$. Again, these results suggest recent spread of the southern lineage eastwards over the Alps and into the northern Balkans.

\section{Two glacial refugia in Iberia}

The occurrence of two field vole subphylogroups in the Iberian Peninsula is consistent with observations in a rapidly growing number of species from a wide array of taxa demonstrating distinct genetic subdivisions across the peninsula (reviewed in Gomez and Lunt, 2003). In fact, it appears that vicariance has been a very common theme in the evolutionary history of the Iberian fauna and flora. The net divergence of $3.8 \%$ between the two field vole subphylogroups suggests that the population split within the southern lineage dates back $0.4 \mathrm{Myr}$ $(\mathrm{CI}=0.2-0.9 \mathrm{Myr})$, that is several glaciations ago. How- ever, the limited cytochrome $b$ variation observed in the Portuguese subphylogroup suggests that it may have experienced a recent bottleneck, and, if so, the genetic distance between the two sublineages may give a slight overestimate of the time of divergence. In any case, a historical scenario involving two glacial refugia for the southern lineage in the Iberian Peninsula at least during the last glaciation seems probable. Gomez and Lunt (2003) recognised at least seven putative glacial refugia for terrestrial taxa in the Iberian Peninsula. The precise location of the two putative field vole refugia is unknown, but most likely one was in central Portugal and the other was somewhere in northern Spain (cf Gomez and Lunt, 2003). Additional phylogeographic studies, particularly with nuclear markers, will hopefully tell us more (cf Avise, 2000).

\section{Conclusions}

The south European mtDNA lineage in the field vole provides a particularly striking example of cryptic divergence. Although mtDNA, $X$ and $Y$ chromosome DNA data demonstrate the distinctiveness of this phylogroup, it has not been recognised previously by either morphology or karyotype. It is, nevertheless, clear that the southern phylogroup represents an ancient evolutionary unit with an interesting history and that it constitutes a notable addition to south European small mammal biodiversity.

\section{Acknowledgements}

We are most grateful to the following friends and colleagues for generously providing specimens for this study: Vincent Bachau, Josefina Barreiro, Alain Butet, François Catzeflis, Jorge González-Esteban, Guila Ganem, Ferenc Jánoska, Maria José López-Fuster, Voitto Haukisalmi, Heikki Henttonen, Nátalia Martínková, Maria da Luz Mathias, Dumitru Murariu, Edyta Owadowska, Françoise Poitevin, Jean Pierre Quere, Mirosław Ratkiewicz, Karl Sperling, Davorin Tome, Peter Vogel, Vitaly Volobouev, Jan Wójcik and Jan Zima. We also thank Susan Haynes for advice regarding laboratory techniques, and Bengt Olle Bengtsson, Karl Fredga, Nátalia Martínková, Håkan Tegelström and an anonymous reviewer for constructive comments on an earlier version of the manuscript. Funding was provided by the Swedish Institute (postdoctoral grant to MJ), the Swedish Natural Science Research Council, the Nilsson-Ehle Foundation and the Lars Hiertas Minnes Foundation.

\section{References}

Almaça C (1993). On the Portuguese population of Microtus agrestis (Linnaeus, 1761). Arq Mus Bocage Nova Sér 2: 319-335.

Anderson S, Bankier AT, Barrell BG, Debruijn MHL, Coulson AR, Drouin J et al (1981). Sequence and organisation of the human mitochondrial genome. Nature 290: 457-465.

Avise JC (2000). Phylogeography. The History and Formation of Species, Cambridge University Press: Cambridge, MA.

Barlow KE, Jones G, Barratt EM (1997). Can skull morphology be used to predict ecological relationships between bat species? A test using two cryptic species of pipistrelle. Proc $R$ Soc Lond B 264: 1695-1700. 
Barratt EM, Deaville R, Burland TM, Bruford MW, Jones G, Racey PA et al (1997). DNA answers the call of pipistrelle bat species. Nature 387: 138-139.

Barton NH, Wilson I (1995). Genealogies and geography. Phil Trans $R$ Soc Lond B 349: 49-59.

Bensasson D, Zhang D-X, Hartl DL, Hewitt GM (2001). Mitochondrial pseudogenes: evolution's misplaced witnesses. Trends Ecol Evol 16: 314-321.

Bilton DT, Mirol PM, Mascheretti S, Fredga K, Zima J, Searle JB (1998). Mediterranean Europe as an area of endemism for small mammals rather than a source for northwards postglacial colonization. Proc $R$ Soc Lond B 265: 1219-1226.

Blondel J, Aronson J (1999). Biology and Wildlife of the Mediterranean Region, Oxford University Press: Oxford.

Clement M, Posada D, Crandall KA (2000). TCS: a computer program to estimate gene genealogies. Mol Ecol 9: 1657-1660.

Conroy CJ, Cook JA (2000a). Phylogeography of a post-glacial colonizer: Microtus longicaudus (Rodentia: Muridae). Mol Ecol 9: $165-175$.

Conroy CJ, Cook JA (2000b). Molecular systematics of a Holarctic rodent (Microtus: Muridae). J Mammal 81: 344-359.

Corbet GB (1978). The Mammals of the Palaearctic Region: a Taxonomic Review, British Museum (Natural History): London.

Crandall KA, Templeton AR (1993). Empirical tests of some predictions from coalescent theory with applications to intraspecific phylogeny construction. Genetics 134: 959-969.

Gomez A, Lunt DH (2003). Refugia within refugia: patterns of phylogeographic concordance in the Iberian Peninsula. In: Weiss S, Ferrand N (eds) Phylogeography of Southern European Refugia, Kluwer Academic Publishers: Dordrecht, Netherlands.

Hausser J, Jammot D (1974). Étude biométriqueś des mâchoires chez les Sorex du groupe araneus en Europe continentale (Mammalia, Insectivora). Mammalia 38: 324-343.

Haynes S, Jaarola M, Searle JB (2003). Phylogeography of the common vole (Microtus arvalis) with particular emphasis on the colonization of the Orkney archipelago. Mol Ecol 12: 951-956.

Hewitt G (2000). The genetic legacy of the Quaternary ice ages. Nature 405: 907-913.

Hewitt GM (1999). Post-glacial re-colonization of European biota. Biol J Linn Soc 68: 87-112.

Irwin DM, Kocher TD, Wilson AC (1991). Evolution of the cytochrome $b$ gene of mammals. J Mol Evol 32: 128-144.

Jaarola M, Searle JB (2002). Phylogeography of field voles (Microtus agrestis) in Eurasia inferred from mitochondrial DNA sequences. Mol Ecol 11: 2613-2621.

Jaarola M, Tegelström H (1995). Colonization history of north European field voles (Microtus agrestis) revealed by mitochondrial DNA. Mol Ecol 4: 299-310.

Jaarola M, Tegelström H (1996). Mitochondrial DNA variation in the field vole (Microtus agrestis): regional population structure and colonization history. Evolution 50: 2073-2085.
Jaarola M, Tegelström H, Fredga K (1999). Colonization history in Fennoscandian rodents. Biol J Linn Soc 68: 113-127.

Kimura M (1980). A simple method for estimating evolutionary rates of base substitutions through comparative studies of nucleotide sequences. J Mol Evol 16: 111-120.

Kimura M (1981). Estimation of evolutionary distances between homologous nucleotide sequences. Proc Natl Acad Sci USA 78: 454-458.

Kumar S, Tamura K, Jakobsen IB, Nei M (2001). MEGA2: molecular evolutionary genetics analysis software. Bioinformatics 17: 1244-1245.

Maddison DR, Maddison WP (2000). MacClade 4: Analysis of Phylogeny and Character Evolution, v. 4.0, Sinauer Associates: Sunderland, MA.

Mirol PM, Mascheretti S, Searle JB (2000). Multiple nuclear pseudogenes of mitochondrial cytochrome $b$ in Ctenomys (Caviomorpha, Rodentia) with either great similarity to or high divergence from the true mitochondrial sequence. Heredity 84: 538-547.

Mitchell-Jones AJ, Amori G, Bogdanowicz W, Kryštufek B, Reijnders PJH, Spitzenberger F et al (1999). The Atlas of European Mammals, Poyser: London.

Myers N, Mittermeier RA, Mittermeier CG, da Fonseca GAB, Kent J (2000). Biodiversity hotspots for conservation priorities. Nature 403: 853-858.

Nei M (1987). Molecular Evolutionary Genetics, Columbia University Press: New York.

Nordborg M (2001). Coalescent theory. In: Balding D, Bishop M, Cannings C (eds) Handbook of Statistical Genetics, Wiley: Chichester pp 179-212.

Posada D, Crandall KA (1998). Modeltest: testing the model of DNA substitution. Bioinformatics 14: 817-818.

Riddle BR, Hafner DJ, Alexander LF, Jaeger JR (2000). Cryptic vicariance in the historical assembly of a Baja California Peninsular Desert biota. Proc Natl Acad Sci USA 97: 14438-14443.

Searle JB (1984). Three new karyotypic races of the common shrew Sorex araneus (Mammalia: Insectivora) and a phylogeny. Syst Zool 33: 184-194.

Sullivan J, Markert JA, Kilpatrick W (1997). Phylogeography and molecular systematics of the Peromyscus aztecus species group (Rodentia: Muridae) inferred using parsimony and likelihood. Syst Biol 46: 426-440.

Swofford DL (1998). PAUP*. Phylogenetic Analysis Using Parsimony ( ${ }^{*}$ and other methods). v. 4, Sinauer Associates, Sunderland, MA.

Taberlet P, Fumagalli L (1996). Owl pellets as a source of DNA for genetic studies of small mammals. Mol Ecol 5: 301-305.

Taberlet P, Fumagalli L, Wust-Saucy AG, Cosson JF (1998). Comparative phylogeography and postglacial colonization routes in Europe. Mol Ecol 7: 453-464.

Wayne RK, Leonard JA, Cooper A (1999). Full of sound and fury: the recent history of ancient DNA. Ann Rev Ecol Syst 30: 457-477. 